\title{
Hepatitis D: challenges in the estimation of true prevalence and laboratory diagnosis
}

\author{
Lin-Yuan Chen ${ }^{1}$, Xiao-Yu Pang ${ }^{1}$, Hemant Goyal ${ }^{2}$, Rui-Xia Yang ${ }^{1 *}$ and Hua-Guo Xu ${ }^{1 *}$ (1)
}

\begin{abstract}
Hepatitis delta virus (HDV) is a defective single negative chain RNA virus, as its envelope protein synthesis is dependent on hepatitis B virus (HBV). Studies have consistently shown that coinfection of HBV and HDV is the most serious form of viral hepatitis, with accelerated progression to liver cirrhosis and hepatocellular carcinoma. About 74 million of HBV surface antigen (HBsAg) positive patients worldwide are also co-infected with HDV. Besides, patients with intravenous drug use and high-risk sexual behavior are at higher risk of HDV infection. Therapeutic schedules for HDV are limited, and relapse of HDV has been observed after treatment with pegylated interferon alpha. To reduce the transmission of HDV, all people infected with HBV should be screened for HDV. At present, several serological and molecular detection methods are widely used in the diagnosis of HDV. However, due to the lack of international standards diagnostic results from different laboratories are often not comparable. Therefore, the true prevalence of HDV is still unclear. In this manuscript, we have analyzed various factors influencing the estimation of HDV prevalence. We have also discussed about the advantages and disadvantages of currently available HDV laboratory diagnostic methods, in order to provide some ideas for improving the detection of HDV.
\end{abstract}

Keywords: Hepatitis delta virus, Hepatitis D, Hepatitis B, Prevalence, Diagnostics

\section{Introduction}

Hepatitis Delta virus (HDV) is a blood-borne pathogen that is dependent on the hepatitis B virus (HBV) for its life cycle. HDV was first identified in HBV-infected patients with severe hepatitis by Rizzetto et al. in 1977 [1]. Initially, HDV was thought to be a new HBV antigen, which was named delta antigen. However, later it was found to have a unique structural component of infectious pathogens and associated with HBV surface antigen (HBsAg) in experimentation with chimpanzees [2]. Wang et al. cloned and sequenced the genome, and it turned out to be a unique RNA virus [3]. HDV is the only member of the delta virus genus, originating from plant viroids or cellular circular ribonucleic acids [4]. HDV is currently the smallest virus capable of infecting humans

\footnotetext{
*Correspondence: yangruixia@jsph.org.cn; huaguoxu@njmu.edu.cn

${ }^{1}$ Department of Laboratory Medicine, the First Affiliated Hospital of Nanjing Medical University, Nanjing, China

Full list of author information is available at the end of the article
}

[5], with a particle diameter of $36 \mathrm{~nm}$ and a genome of only about $1.7 \mathrm{~kb}$ which can encode two forms of hepatitis D antigen (HDAg), namely the small HDAg (S-HDAg) and the large HDAg (L-HDAg) [6]. S-HDAg has 19-20 fewer amino acids than L-HDAg, but they come from the common $0.8 \mathrm{~kb}$ mRNA [7]. S-HDAg is necessary to initiate and maintain HDV RNA replication [8], while L-HDAg inhibits HDV replication [9], but is crucial for the assembly of virions [10]. The HDAg binds to the HDV genome to form a ribonucleoprotein (RNP) complex. The HDV genome contains two self-cleaving motifs called ribozyme regions [11], located upstream to the region coding for HDAg (Fig. 1). HDV replicates only in liver nuclei, but the virion is defective. As an envelope protein, HBsAg allows HDV to enter hepatocytes. HDV and HBV first bind to heparan sulphate proteoglycans (HSPGs) on the surface of hepatocytes [12] and then enter host cells via sodium taurocholate cotransporting polypeptide (NTCP) [13]. After membrane fusion, RNP is released and further transported to the nucleus, where the mRNA original author(s) and the source, provide a link to the Creative Commons licence, and indicate if changes were made. The images or other third party material in this article are included in the article's Creative Commons licence, unless indicated otherwise in a credit line to the material. If material is not included in the article's Creative Commons licence and your intended use is not permitted by statutory regulation or exceeds the permitted use, you will need to obtain permission directly from the copyright holder. To view a copy of this licence, visit http://creativecommons.org/licenses/by/4.0/. The Creative Commons Public Domain Dedication waiver (http://creativeco mmons.org/publicdomain/zero/1.0/) applies to the data made available in this article, unless otherwise stated in a credit line to the data. 


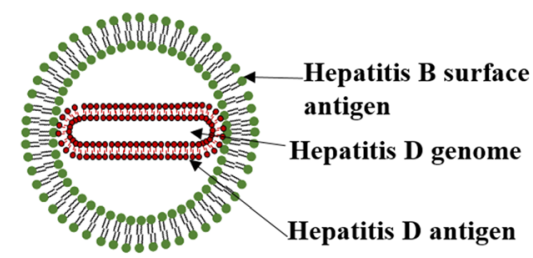

A. Hepatitis D virion

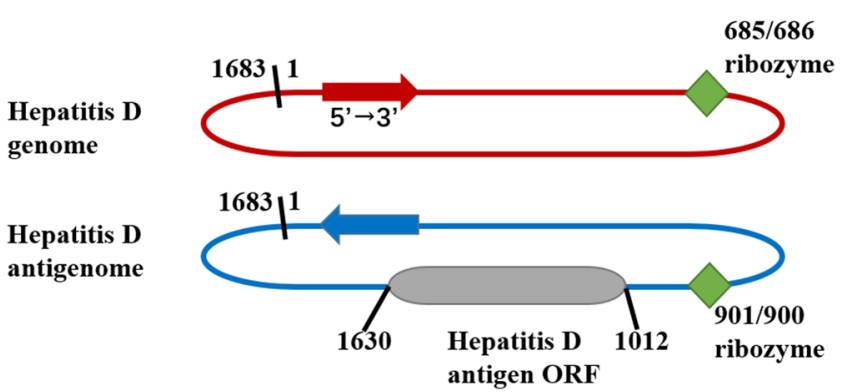

Fig. 1 HDV virion and nucleic acid structure diagram. A HDV virion has a ribonucleoprotein (RNP) complex inside and an HBV derived envelope outside. The RNP consists of the HDV genome and two isoforms of hepatitis D antigen (HDAg), L-HDAg and S-HDAg. B Structure of HDV RNA. Both genome and antigenome form an unbranched rod-like structure of $1700 \mathrm{bp}$ containing a self-cleaving ribozyme (green boxs). The gray box represents HDAg ORF. Arrows on the RNA strands indicate the $5^{\prime}-3^{\prime}$ direction. HDV hepatitis D virus; L-HDAg large hepatitis D antigen; S-HDAg small hepatitis D antigen

encoding S-HDAg is transcribed and translated. The entering genomic RNA serves as a template for the first roll-loop amplification. The resulting antigenomic RNA polymers are cleaved by self-cleaving RNA sequences (namely ribozyme) and linked into circular monomers [14]. Using antigenomic RNA as a template, the HDV genomic RNA polymers are synthesized and further cleaved to form monomers. Editing of HDV antigenomic RNA by cellular adenosine deaminase 1 (ADAR 1 ) allows L-HDAg transcription and translation [15]. S-HDAg and L-HDAg are transported into the nucleus to regulate viral replication or to bind to HDV RNA to form RNP. RNP containing HDV genomic RNA can be exported to the cytoplasm and encapsulated into the HBV envelope through the interaction between L-HDAg and HBsAg. HDV virions are released through the ER-Golgi secretory pathway. (Fig. 2) In addition to de novo infection dependent on the HBV envelope, HDV can directly transfer replicable HDV RNA between cells during mitosis [16]. There are currently eight HDV genotypes, but HDV has a high degree of genetic heterogeneity [17]. The differences between isolates of the same genotype were less than $16 \%$, while the degree of separation between genotypes was as high as $40 \%$ [18]. The clinical HDV infection can occur in two manners; 1. Coinfection: when HDV and HBV simultaneously infect the host causing acute viral hepatitis, and 2. Superinfection: HDV infection occurring in HBsAg carriers or chronic HBV infected individuals leads to chronic viral hepatitis [19]. Chronic hepatitis $\mathrm{D}$ (CHD) is the most serious type of viral hepatitis in humans [20]. Patients with HDV are more likely to develop liver cirrhosis [21], liver decompensation [22], and are at increased risk of hepatocellular carcinoma (HCC) [23] than other chronic viral hepatitis. Although the underlying mechanisms of HDV infection are not fully understood, HDV load (HDVL) can influence the course of liver disease to some extent [24]. Moreover, there is no available effective treatment for HDV at present [25]. The commonly used pegylated interferon alpha (IFN- $\alpha$ ) inhibits HDV replication in about $25-30 \%$ of patients, but this therapy has side effects and is also associated with late recurrence [26]. The quantification of viral nucleic acid is very important for monitoring the occurrence and development of disease and evaluating the therapeutic effect. Therefore, it is paramount to develop an economical, sensitive and specific international standardized test for the detection of HDV RNA.

\section{Prevalence}

Epidemiological estimates have suggested that about 5\% of patients with hepatitis B were also co-infected with HDV globally, which equated to about 15 million individuals [27]. However, a recent meta-analysis found that the seroprevalence of HDV in mixed population was about 10.07\% between 1977 and 2018, meaning that about 74 million people worldwide were infected with HDV [28]. At the same time, Miao et al. analyzed articles published from 1980 to 2019 and suggested that the total prevalence of HDV among HBV carriers was $13.02 \%$, corresponding to 48-60 million individuals worldwide [29]. In addition, another study, which searched and analyzed articles from 1st January 1998 to 28th January 2019, Q-MAC suggested that the prevalence of HDV in all HBsAg positive patients was about $4.5 \%$, or about 12 million people worldwide were infected with HDV [30]. These differences in the variation in HDV prevalence estimates could be due to several reasons. First of all, the criteria for inclusion and exclusion of the literature varied significantly producing different prevalence. Most of the published literature used the presence of HDV antibodies as the diagnostic criteria, but anti-HDV positivity may not differentiate between an existing or a past infection 


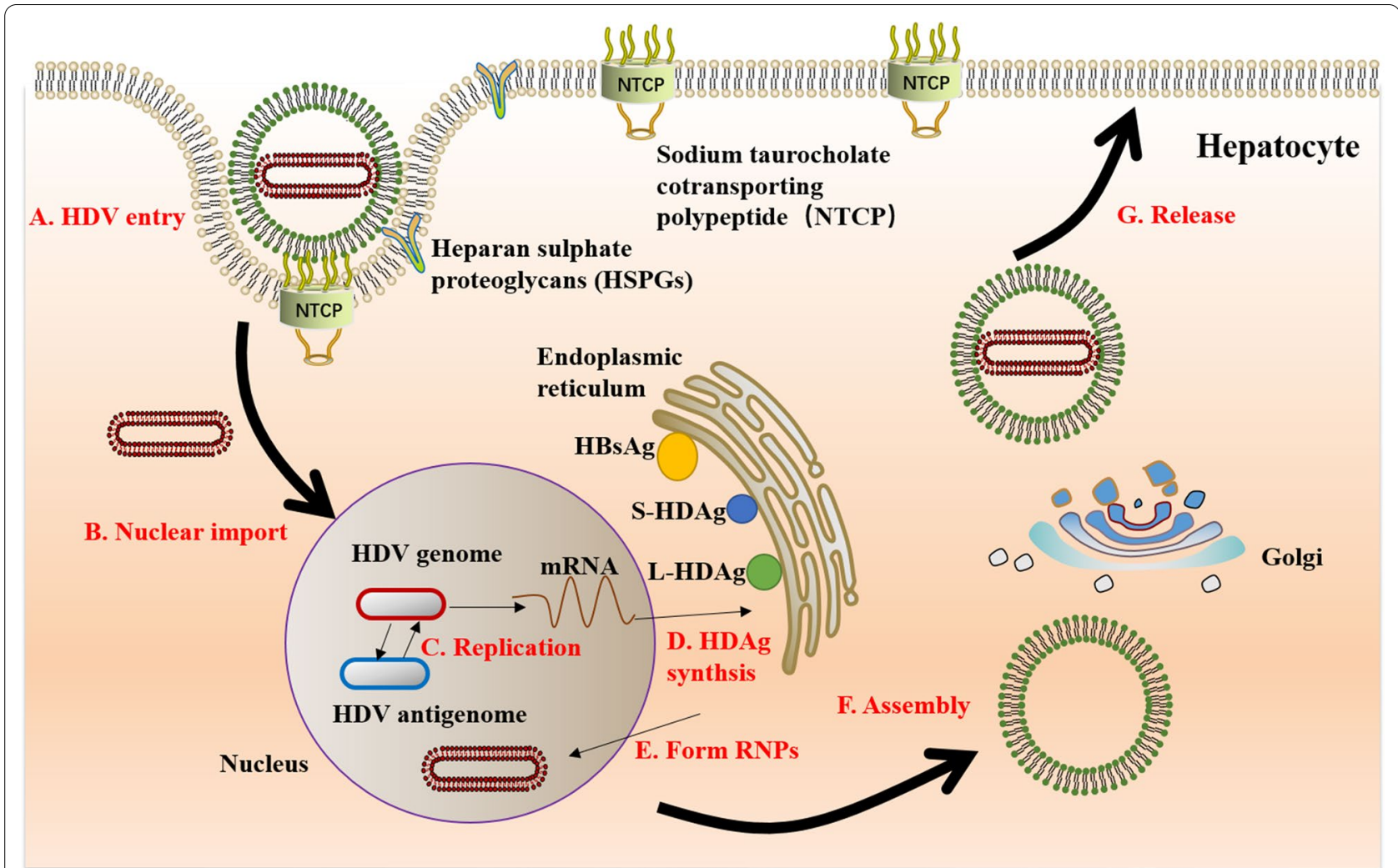

Fig. 2 Schematic representation of HDV life cycle. A HDV virion enters the hepatocyte via HSPGs and NTCP. B The virion loses its envelope and the RNP is imported into the nucleus of the cell. C Within the nucleolus, HDV RNA is replicated using a double rolling circle amplification to form the antigenomic RNA and more genomic RNA. D The mRNA is exported to the cytoplasm where it is translated at the endoplasmic reticulum (ER) to form HDAg. E HDAg return to the nucleus where the S-HDAg isoform promotes further genome replication. S-HDAg and L-HDAg bind to new transcripts of genomic RNA to form new RNPs. $\mathbf{F}$ RNPs are exported to the cytoplasm where L-HDAg facilitates association with HBsAg in the ER to assemble new virus particles. G They are then released out of the hepatocyte via the Golgi to infect neighboring cells. HDV hepatitis D virus; $L-H D A g$ large hepatitis D antigen; S-HDAg small hepatitis D antigen; HBsAg hepatitis B surface antigen; RNP ribonucleoprotein; mRNA messenger RNA; NTCP sodium taurocholate cotransporting polypeptide; HSPGs heparan sulphate proteoglycans

[31]. Second, the prevalence and the genotype distribution of HDV vary widely in different countries and regions. The prevalence of HDV is high in Central Asia, Eastern Europe, West Africa and the Amazon basin [31]. However, due to a limited number of studies in some countries, the estimated value may not represent the true prevalence in those countries [32]. Besides, patients with intravenous drug use (IVDU), high-risk sexual behavior (HRSB), human immunodeficiency virus (HIV) or hepatitis $\mathrm{C}$ virus $(\mathrm{HCV})$ infections are at higher risk of HDV infection [32]. Thus, the current prevalence of HDV is still controversial. High-quality global studies with consistent inclusion and exclusion criteria are needed to estimate the true prevalence of HDV.

\section{Current laboratory diagnosis}

Traditionally, the diagnosis of a viral disease has relied on culture-based methods that directly detect the intact virus or its components (proteins or nucleic acids) or serological tests that indirectly detect the antigens or antibodies of the viruses [33]. Nowadays, polymerase chain reaction (PCR)-based methods are widely used in virus diagnosis because of their high specificity, sensitivity and ease of operation. These tests can rapidly amplify certain parts of the genome necessary for virus identification. Current methods for detecting HDV RNA are described below.

\section{Serological diagnosis}

Not long after discovery of HDV, antibody tests were developed and marketed as serological markers of HDV infection [34]. Currently, antibody testing is often used as a primary screening test for HDV infection, with detection of antibody to the HDAg (anti-HDV) by enzyme-linked immunosorbent assay (ELISA) or radioimmunoassay (RIA). The immunoglobulin M (IgM) anti-HDV is detectable within 2-3 weeks of symptom onset and disappears 2 months after acute infection [35]. 
However, anti-HDV IgM is also elevated in patients with chronic HDV during disease flares [36], so detection of anti-HDV IgM cannot definitively distinguish between acute and chronic HDV infections. The anti-HDV IgG is positive in patients with acute remission of HDV infection and chronic HDV infection, and persists for a long time after virus clearance, making it difficult to distinguish between present and previous HDV infections (Fig. 3). Chen et al. have used protein microarray technology to develop a Q-MAC assay for sensitive quantitative fluorescent detection of anti-HDV IgG from patient sera [37]. Anti-HDV IgG has been quantitatively detected by quantitative microarray antibody capture (Q-MAC) in Mongolia, the United States and the Gambia [37-39]. Although there is a certain correlation between the fluorescence intensity of Q-MAC and HDV RNA, the relationship could not be determined for co-infection with hepatitis $\mathrm{C}$ virus $(\mathrm{HCV})$, also known as triple hepatitis virus infection [38, 40]. HDAg is expressed in liver cell nuclei and can be detected by immunochemistry. Detection of serum HDAg is limited and detectable in the first 2 weeks of acute infection [41]. Intrahepatic HDAg can be detected by immunohistochemistry in liver biopsy samples, but this method is not commonly used.

\section{Molecular diagnosis}

The HDV nucleic acid quantitative analysis can be used to both diagnose and monitor the treatment outcomes. The routine PCR cannot be used to detect HDVL as the HDV genome is made of RNA, not DNA [42]. Real-time quantitative reverse transcript PCR (RT-qPCR) is to add a signal system based on traditional PCR to achieve the purpose of real-time quantitative detection of samples. According to the different signal, groups can be divided into fluorescent dye method and probe method. Currently, there are a number of internal methods and commercial kits available for quantitative determination of HDV RNA (Table 1). These techniques are designed to target the sequences coding for the conserved regions of the HDAg or the ribozyme domain. HDV genome has a robust secondary structure, which can be destroyed by adding heat shock treatment prior to the reverse transcriptional step [43-47], thus improving reverse transcriptional efficiency. The use of one-step RT-qPCR reduces the risk of contamination during reverse transcription and amplification [47-50]. The standard used in most published studies is HDV plasmid DNA [43-46, 51-53], but this does not assess reverse transcriptional steps. Other studies have used RNA synthesized in vitro as the standard [47, 48, 50, 54, 55]. Although reverse transcription steps can be evaluated, the synthesized RNA does not have a strong secondary structure, and the secondary structure of the HDV genome also affects the quantitative viral load. In the sixty-fourth report of the World Health Organization (WHO) Expert Committee on Biological Standardization, a sample with a high HDV titer (code 7657/12) was tested in 19 laboratories around the world with a lower limit of 5,75,000 IU/ $\mathrm{mL}$, based on the averages reported by different assay methods [56,57]. Although the WHO has proposed an

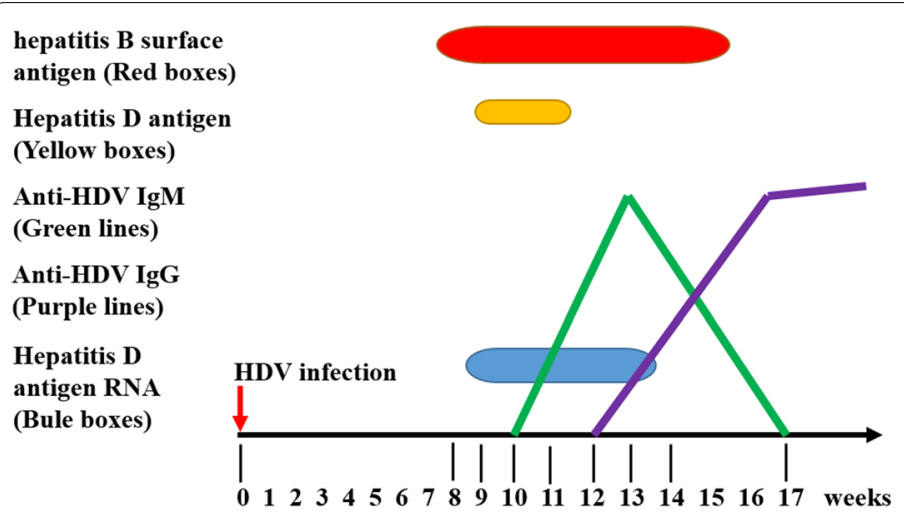

A. Coinfection

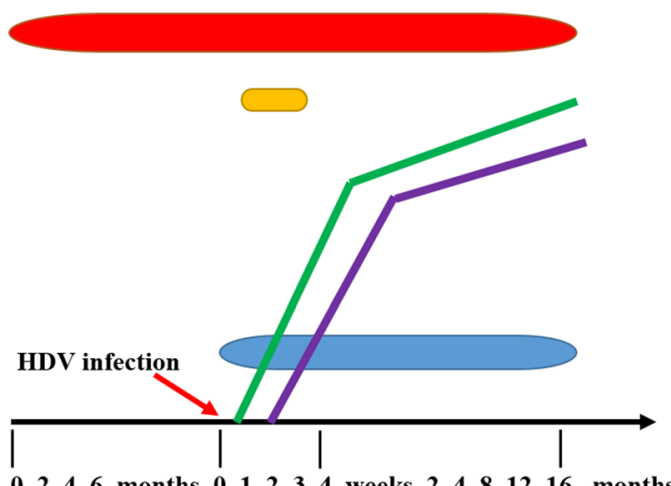

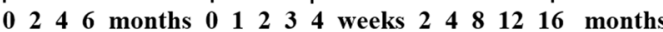

\section{B. Superinfection}

Fig. 3 Serological patterns of HDV infection. A Coinfection is the simultaneous acute infection of HBV and HDV in a susceptible individual. Serum HDAg is detectable only transiently in blood specimens collected early at the onset of HDV, before the rising of antibodies. Anti-HDV IgM response is rapid and weak suggesting a resolution of infection. Anti-HDV IgG levels increased rapidly and persisted. B Superinfection is an HDV infection in an individual chronically infected with HBV. This pattern of infection has two components, the acute stage and the chronic stage. The acute phase is characterized by very high levels of HDV viremia and HDAg antigen in serum/liver. In the chronic period, HDV RNA, anti-HDV IgM and anti-HDV IgG persist. HDAg can be detected by liver biopsy. HDV hepatitis D virus; HBV hepatitis B virus; HDAg hepatitis D antigen; HBs Ag hepatitis B surface antigen; Anti-HDV IgM immunoglobulin M antibody to the HDAg; Anti-HDV IgG immunoglobulin G antibody to the HDAg 


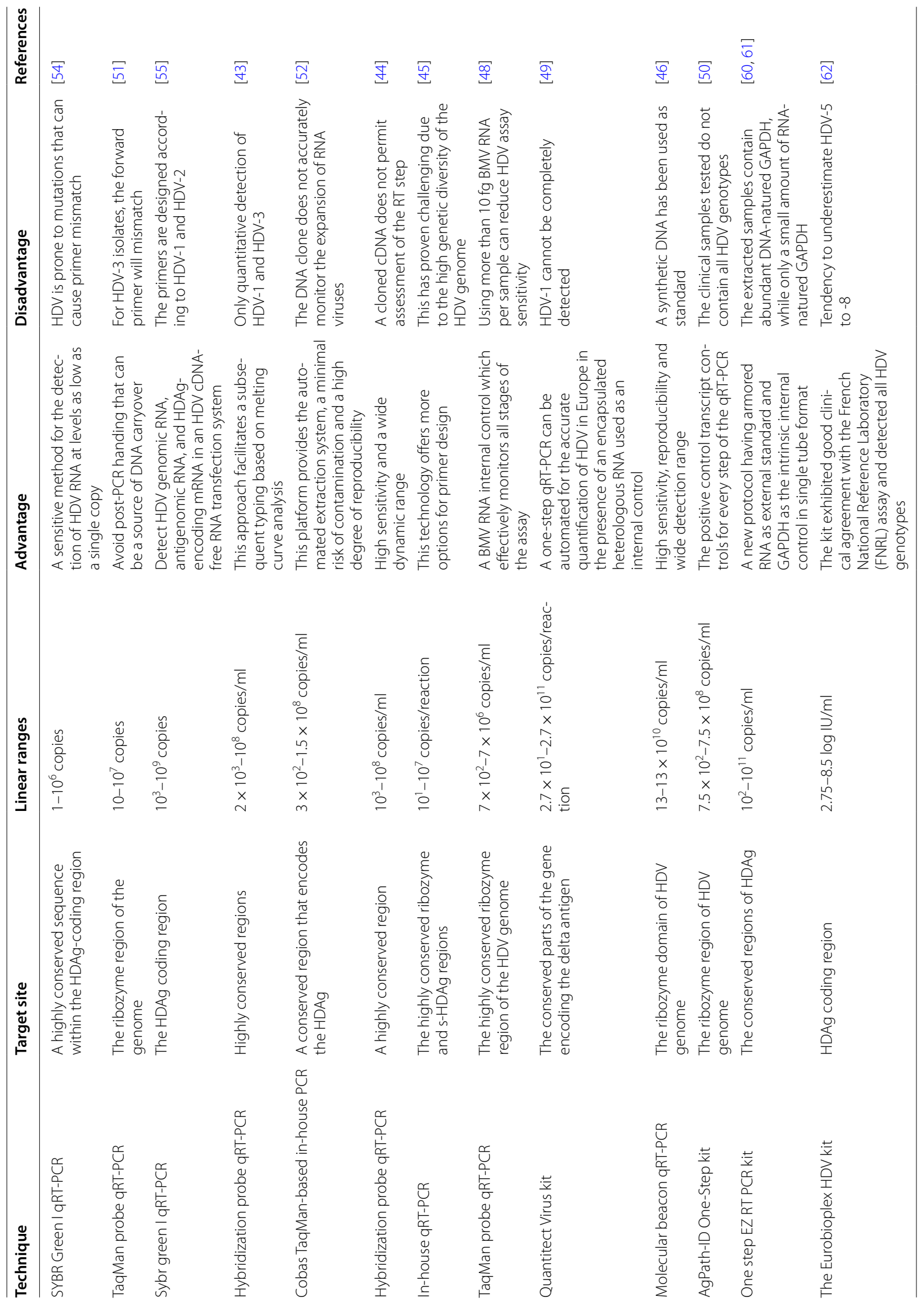


international standard for HDV RNA tests, but it still needs internal control, which should be co-purified and co-amplified with the nucleic acid being tested. Competitive RNA internal controls have been devised that use the same primers to detect both the control and the target virus [58]. However, detection accuracy decreases when the target viral load is low. Noncompetitive internal controls have also been described, using separate primers to detect controls and samples. Some housekeeping genes such as $\beta$-actin and 18S rRNA are used for internal controls [59]. Unfortunately, the concentrations of these RNAs varied greatly among clinical samples. After Karataylı et al. put forward the free circulating nucleic acids in plasma and serum (CNAPS) that is Glyceraldehyde-3-phosphate dehydrogenase (GAPDH) as internal reference [60]. However, the authors found that the nature of freely circulating GAPDH in serum was mostly in DNA nature and a small portion of GAPDH in RNA nature by RNAse or DNAse digestion in a number of HDV and HBV patients. Therefore, GAPDH is not an ideal internal control for detecting RNA viruses [61]. Ferns et al. used heterogenous RNA that is Brome Mosaic virus (BMV) RNA, as an internal control. $10 \mathrm{fg}$ BMV RNA was added to each sample and the RNA was extracted. RT-qPCR assay was performed using specific primers/probes of HDV and BMV. Full-length genomic HDV RNA was used as calibration criteria. However, when the HDV RNA concentrations below 7000 copies/ $\mathrm{ml}$, the detection became less accurate. Moreover, the use of more than $10 \mathrm{fg}$ BMV RNA per sample would reduce the sensitivity of HDV detection [48]. Although a number of commercial tests have been developed for HDV RNA quantification [49, 50,60-62], they underestimate or fail to quantify HDVL [63]. The international external quality assessment for HDV RNA quantification in plasma was first conducted in 2016. A comprehensive analysis of 28 laboratories in 17 countries worldwide showed that the results were highly heterogeneous due to the differences in the detection techniques and procedures, and the different target areas for which the primers or probes were designed [64]. Therefore, it is necessary to establish an international detection system for the quantification of HDV RNA. In addition, Wang et al. detected HDV genotype 1 by reverse transcription-loop-mediated isothermal amplification (RT-LAMP) [65]. LAMP employs DNA polymerase, a set of four specially designed primers that can identify a total of six different sequences in the target DNA [66]. RT-LAMP is similar to LAMP, but the template used is RNA instead of DNA. Compared with conventional PCR, LAMP is simple to operate, only needs to be incubated under isothermal conditions, and can quickly and efficiently amplify the target sequence in a short time. However, as the LAMP technology can identify white precipitate with naked-eye, its detection results cannot be quantified accurately [67]. Different genotypes of HDV have an impact on the clinical outcome of infection, with genotype 1 being the most common genotype and having variable pathogenicity [68]. The genotypes of HDV can be determined by phylogenetic analysis, providing evidence for more accurate diagnosis of HDV in clinic [69].

\section{Diagnosis challenges}

Several issues exist for the correct diagnosis of HDV, ultimately affecting its true prevalence. Ideally, HDV diagnosis should be made with the identification of both HDV antibody and RNA, to distinguish between the chronic and previous infections, and to monitor treatment response [70]. Most antibody tests are ELISA kits, but the accuracy of internal and commercial quantitative analysis of HDV RNA varies significantly, and sometimes HDV RNA cannot be detected in HDV RNA-positive samples [64]. Bremer et al. found that automated nucleic acid isolation led to viral load underestimation by comparing manual and four automated HDV RNA extraction methods (AmpliPrep, MagNA Pure, QlAcube QBK and QlAcube VRK) [24]. Moreover, the secondary structure and different HDV genotypes should be considered when designing primers and probes [64]. Besides, the choice of quality control products will also affect the accurate quantification of HDV RNA. The ideal viral nucleic acid quality control products can not only be used for the quality control of nucleic acid detection process, but also an important material basis for the evaluation of detection procedures and the comparison of results between different laboratories [71]. At present, the quality control products of RNA viruses are mostly bare RNA fragments or whole virus particles. Bare RNA fragments, as quality controls, are easily degraded by RNase in the environment and cannot effectively react with to the nucleic acid extraction process [72]. Traditional RNA preservatives such as alcohols and guanidine can lead to RNA degradation [73]. RNAlater is a good RNA stabilizer, but has different effects on enveloped and non-enveloped viruses. For example, at room temperature, after long term storage of RNAlater, the cellular infectivity of non-enveloped enterovirus remained high, but the cellular infectivity of enveloped vesicular stomatitis virus decreased [74]. The whole virus particles, especially the inactivated virus particles, have safety risks as quality control materials. Although inactivated drugs can reduce infectivity, there is still a risk of incomplete inactivation, and virus inactivation reagents (such as formaldehyde) will destroy viral nucleic acid, affecting the extraction of its nucleic acid [75]. The ideal RNA quality control products should be stored for a long time without degradation or loss of 
copy number [76]. Armored RNA technology can overcome RNA instability and has been widely used in the research of RNA viral nucleic acid quality control products. Pasloske et al. invented armored RNA by building the quality controls for HIV [77]. The principle of this technology is the use of genetic engineering methods to clone a sequence containing phage coat protein gene and target fragment into the expression vector. The vector transcribed the cloned fragment into recombinant RNA and assembled it into spherical RNA-protein complex, namely RNA virus-like particles, using the shell protein synthesized from the shell protein gene on the vector [78], thus preventing the RNA degradation.

\section{Conclusion}

Although the true prevalence of HDV remains unclear, multiple epidemiological studies, have revealed that the global burden of HDV is higher than previously estimated. Rapid laboratory diagnosis of HDV infection is of significant importance for identifying, monitoring, and controlling the disease spread. At present, the sensitivity of different HDV RNA detection methods varies substantially, and there is a lack of international unified detection standard for comparable results between different laboratories. In addition, insufficient healthcare access in low-and middle-income countries often leads to underdiagnoses of the disease hindering the early diagnosis and effective treatment. The RT-qPCR assay has been developed. However, the development of new detection methods is still needed that not only have high sensitivity and specificity but also can monitor a series of processes such as HDV RNA extraction, reverse transcription, and quantification, thereby reducing false-negative rates, identifying HDV patients earlier, and controlling HDV transmission in a timely manner. In addition, standardized procedures need to be established, such as sample type, extraction method, primer/probe designs, protocols, instrumentation, and reporting units. Therefore, the future goal is to standardize these tests for the accurate detection of HDV. It is possible that further innovations, such as mass spectrometry and real-time biosensor platforms, will detect HDV RNA or its components and monitor its occurrence.

\section{Acknowledgements \\ Not applicable.}

\section{Authors' contributions}

All authors read and approved the final manuscript.

\section{Funding}

Natural Science Foundation of Jiangsu Province of China (BK20181492), the National Key Clinical Department of Laboratory Medicine of China in Nanjing, the Key Laboratory for Laboratory Medicine of Jiangsu Province (ZDXKB2016005) and the Priority Academic Program Development of Jiangsu Higher Education Institutions.
Availability of data and materials

Not applicable.

\section{Declarations}

Ethics approval and consent to participate

Not applicable.

\section{Consent for publication \\ Not applicable.}

\section{Competing interests}

The authors declare that they have no competing interests.

\section{Author details}

${ }^{1}$ Department of Laboratory Medicine, the First Affiliated Hospital of Nanjing Medical University, Nanjing, China. ${ }^{2}$ Department of Internal Medicine Macon, Mercer University School of Medicine, Georgia, USA.

Received: 7 June 2021 Accepted: 19 October 2021

Published online: 30 October 2021

References

1. Rizzetto M, Canese MG, Arico S, Crivelli O, Trepo C, Bonino F, et al. Immunofluorescence detection of new antigen-antibody system (delta/ anti-delta) associated to hepatitis B virus in liver and in serum of $\mathrm{HBsAg}$ carriers. Gut. 1977:18(12):997-1003.

2. Rizzetto M, Hoyer B, Canese MG, Shih JW, Purcell RH, Gerin JL. delta Agent: association of delta antigen with hepatitis B surface antigen and RNA in serum of delta-infected chimpanzees. Proc Natl Acad Sci USA. 1980;77(10):6124-8

3. Wang KS, Choo QL, Weiner AJ, Ou JH, Najarian RC, Thayer RM, et al. Structure, sequence and expression of the hepatitis delta (delta) viral genome. Nature. 1986;323(6088):508-14.

4. Taylor JM. Host RNA circles and the origin of hepatitis delta virus. World J Gastroenterol. 2014;20(11):2971-8.

5. Negro F. Hepatitis D virus coinfection and superinfection. Cold Spring Harb Perspect Med. 2014;4(11):a021550.

6. Weiner AJ, Choo QL, Wang KS, Govindarajan S, Redeker AG, Gerin JL, et al. A single antigenomic open reading frame of the hepatitis delta virus encodes the epitope(s) of both hepatitis delta antigen polypeptides p24 delta and p27 delta. J Virol. 1988;62(2):594-9.

7. Luo GX, Chao M, Hsieh SY, Sureau C, Nishikura K, Taylor J. A specific base transition occurs on replicating hepatitis delta virus RNA. J Virol. 1990;64(3):1021-7.

8. Glenn JS, White JM. trans-dominant inhibition of human hepatitis delta virus genome replication. J Virol. 1991;65(5):2357-61.

9. Chao M, Hsieh SY, Taylor J. Role of two forms of hepatitis delta virus antigen: evidence for a mechanism of self-limiting genome replication. J Virol. 1990;64(10):5066-9.

10. Chang FL, Chen PJ, Tu SJ, Wang CJ, Chen DS. The large form of hepatitis delta antigen is crucial for assembly of hepatitis delta virus. Proc Natl Acad Sci USA. 1991;88(19):8490-4.

11. Ferré-D'Amaré AR, Zhou K, Doudna JA. Crystal structure of a hepatitis delta virus ribozyme. Nature. 1998:395(6702):567-74.

12. Verrier ER, Colpitts CC, Bach C, Heydmann L, Weiss A, Renaud M, et al. A targeted functional RNA interference screen uncovers glypican 5 as an entry factor for hepatitis B and D viruses. Hepatology. 2016;63(1):35-48.

13. Li J, Wands J. Hepatitis B and D viral receptors. Hepatology. 2016;63(1):11-3.

14. Sharmeen L, Kuo MY, Dinter-Gottlieb G, Taylor J. Antigenomic RNA of human hepatitis delta virus can undergo self-cleavage. J Virol. 1988;62(8):2674-9.

15. Wong SK, Lazinski DW. Replicating hepatitis delta virus RNA is edited in the nucleus by the small form of ADAR1. Proc Natl Acad Sci USA. 2002;99(23):15118-23. 
16. Giersch K, Bhadra OD, Volz T, Allweiss L, Riecken K, Fehse B, et al. Hepatitis delta virus persists during liver regeneration and is amplified through cell division both in vitro and in vivo. Gut. 2019;68(1):150-7.

17. Le Gal F, Gault E, Ripault M-P, Serpaggi J, Trinchet J-C, Gordien E, et al. Eighth major clade for hepatitis delta virus. Emerg Infect Dis. 2006;12(9):1447-50.

18. Dény P. Hepatitis delta virus genetic variability: from genotypes I, II, III to eight major clades? Curr Top Microbiol Immunol. 2006;307:151-71.

19. Caredda F, Rossi E, d'Arminio Monforte A, Zampini L, Re T, Meroni B, et al. Hepatitis B virus-associated coinfection and superinfection with delta agent: indistinguishable disease with different outcome. J Infect Dis. 1985;151(5):925-8.

20. Smedile A, Farci P, Verme G, Caredda F, Cargnel A, Caporaso N, et al. Influence of delta infection on severity of hepatitis B. Lancet. 1982;2(8305):945-7

21. Fattovich G, Boscaro S, Noventa F, Pornaro E, Stenico D, Alberti A, et al. Influence of hepatitis delta virus infection on progression to cirrhosis in chronic hepatitis type B. J Infect Dis. 1987;155(5):931-5.

22. Fernández-Montero JV, Vispo E, Barreiro P, Sierra-Enguita R, de Mendoza C, Labarga $\mathrm{P}$, et al. Hepatitis delta is a major determinant of liver decompensation events and death in HIV-infected patients. Clin Infect Dis. 2014;58(11):1549-53.

23. Sureau C, Negro F. The hepatitis delta virus: replication and pathogenesis. J Hepatol. 2016;64(1 Suppl):S102-16.

24. Bremer B, Anastasiou OE, Ciesek S, Wedemeyer H. Automated nucleic acid isolation methods for HDV viral load quantification can lead to viral load underestimation. Antivir Ther. 2019;24(2):117-23.

25. Caviglia GP, Rizzetto M. Treatment of hepatitis D: an unmet medical need. Clin Microbiol Infect Off publ Eur Soc Clin Microbiol Infect Dis. 2020;26(7):824-7.

26. Wranke A, Wedemeyer $\mathrm{H}$. Antiviral therapy of hepatitis delta virus infection-progress and challenges towards cure. Curr Opin Virol. 2016;20:112-8.

27. Lempp FA, Ni Y, Urban S. Hepatitis delta virus: insights into a peculiar pathogen and novel treatment options. Nat Rev Gastroenterol Hepatol. 2016;13(10):580-9.

28. Shen D-T, Ji D-Z, Chen H-Y, Goyal H, Pan S, Xu H-G. Hepatitis D: not a rare disease anymore: global update for 2017-2018. Gut. 2020;69(4):786-8.

29. Miao Z, Zhang S, Ou X, Li S, Ma Z, Wang W, et al. Estimating the global prevalence, disease progression, and clinical outcome of hepatitis delta virus infection. J Infect Dis. 2020;221(10):1677-87.

30. Stockdale AJ, Kreuels B, Henrion MYR, Giorgi E, Kyomuhangi I, de Martel $C$, et al. The global prevalence of hepatitis D virus infection: systematic review and meta-analysis. J Hepatol. 2020;73(3):523-32.

31. Wedemeyer $H$, Negro F. Devil hepatitis D: an orphan disease or largely underdiagnosed? Gut. 2019;68(3):381-2.

32. Chen H-Y, Shen D-T, Ji D-Z, Han P-C, Zhang W-M, Ma J-F, et al. Prevalence and burden of hepatitis $D$ virus infection in the global population: a systematic review and meta-analysis. Gut. 2019;68(3):512-21.

33. Mauriz E. Recent progress in plasmonic biosensing schemes for virus detection. Sensors. 2020. https://doi.org/10.3390/s20174745.

34. Vlachogiannakos J, Papatheodoridis GV. New epidemiology of hepatitis delta. Liver Int Off J Int Assoc Study Liver. 2020;40(Suppl 1):48-53.

35. Koh C, Heller T, Glenn JS. Pathogenesis of and new therapies for hepatitis D. Gastroenterology. 2019. https://doi.org/10.1053/j.gastro.2018.09.058.

36. Wranke A, Heidrich B, Ernst S, Calle Serrano B, Caruntu FA, Curescu MG, et al. Anti-HDV IgM as a marker of disease activity in hepatitis delta. PLoS ONE. 2014;9(7):e101002.

37. Chen X, Oidovsambuu O, Liu P, Grosely R, Elazar M, Winn VD, et al. A novel quantitative microarray antibody capture assay identifies an extremely high hepatitis delta virus prevalence among hepatitis B virus-infected mongolians. Hepatology. 2017;66(6):1739-49.

38. Mahale P, Aka PV, Chen X, Liu P, Fram BJ, Wang AS, et al. Hepatitis D viremia among injection drug users in San Francisco. J Infect Dis. 2018;217(12):1902-6.

39. Mahale P, Aka P, Chen X, Pfeiffer RM, Liu P, Groover S, et al. Hepatitis D virus infection, cirrhosis and hepatocellular carcinoma in The Gambia. J Viral Hepatitis. 2019;26(6):738-49.

40. Liaw YF. Role of hepatitis $C$ virus in dual and triple hepatitis virus infection. Hepatology. 1995;22(4 Pt 1):1101-8.
41. Shattock AG, Morris MC. Evaluation of commercial enzyme immunoassays for detection of hepatitis delta antigen and anti-hepatitis delta virus (HDV) and immunoglobulin M anti-HDV antibodies. J Clin Microbiol. 1991;29(9):1873-6.

42. Behera BC, Mishra RR, Thatoi H. Recent biotechnological tools for diagnosis of corona virus disease: a review. Biotechnol Prog. 2020. https://doi. org/10.1002/btpr.3078.

43. Hofmann J, Frenzel K, Minh BQ, von Haeseler A, Edelmann A, Ross SR, et al. Quantitative detection and typing of hepatitis $D$ virus in human serum by real-time polymerase chain reaction and melting curve analysis. Diagn Microbiol Infect Dis. 2010;67(2):172-9.

44. Schaper M, Rodriguez-Frias F, Jardi R, Tabernero D, Homs M, Ruiz G, et al. Quantitative longitudinal evaluations of hepatitis delta virus RNA and hepatitis $B$ virus DNA shows a dynamic, complex replicative profile in chronic hepatitis B and D. J Hepatol. 2010;52(5):658-64.

45. Shang D, Hughes SA, Horner M, Bruce MJ, Dong Y, Carey I, et al. Development and validation of an efficient in-house real-time reverse transcription polymerase chain reaction assay for the quantitative detection of serum hepatitis delta virus RNA in a diverse South London population. J Virol Methods. 2012;184(1-2):55-62.

46. Katsoulidou A, Manesis E, Rokka C, Issaris C, Pagoni A, Sypsa V, et al. Development and assessment of a novel real-time PCR assay for quantitation of hepatitis D virus RNA to study viral kinetics in chronic hepatitis D. J Viral Hepatitis. 2013;20(4):256-62.

47. Homs M, Giersch K, Blasi M, Lütgehetmann M, Buti M, Esteban R, et al. Relevance of a full-length genomic RNA standard and a thermal-shock step for optimal hepatitis delta virus quantification. J Clin Microbiol. 2014;52(9):3334-8.

48. Ferns RB, Nastouli E, Garson JA. Quantitation of hepatitis delta virus using a single-step internally controlled real-time RT-qPCR and a full-length genomic RNA calibration standard. J Virol Methods. 2012;179(1):189-94.

49. Scholtes C, Icard V, Amiri M, Chevallier-Queyron P, Trabaud M-A, Ramière $C$, et al. Standardized one-step real-time reverse transcription-PCR assay for universal detection and quantification of hepatitis delta virus from clinical samples in the presence of a heterologous internal-control RNA.J Clin Microbiol. 2012;50(6):2126-8.

50. Kodani M, Martin A, Mixson-Hayden T, Drobeniuc J, Gish RR, Kamili S. One-step real-time PCR assay for detection and quantitation of hepatitis D virus RNA. J Virol Methods. 2013;193(2):531-5.

51. Le Gal F, Gordien E, Affolabi D, Hanslik T, Alloui C, Dény P, et al. Quantification of hepatitis delta virus RNA in serum by consensus real-time PCR indicates different patterns of virological response to interferon therapy in chronically infected patients. J Clin Microbiol. 2005;43(5):2363-9.

52. Mederacke I, Bremer B, Heidrich B, Kirschner J, Deterding K, BockT, et al. Establishment of a novel quantitative hepatitis D virus (HDV) RNA assay using the Cobas TaqMan platform to study HDV RNA kinetics. J Clin Microbiol. 2010;48(6):2022-9.

53. Pollicino T, Raffa G, Santantonio T, Gaeta GB, lannello G, Alibrandi A, et al. Replicative and transcriptional activities of hepatitis $B$ virus in patients coinfected with hepatitis B and hepatitis delta viruses. J Virol. 2011;85(1):432-9.

54. Yamashiro T, Nagayama K, Enomoto N, Watanabe H, Miyagi T, Nakasone $\mathrm{H}$, et al. Quantitation of the level of hepatitis delta virus RNA in serum, by real-time polymerase chain reaction-and its possible correlation with the clinical stage of liver disease. J Infect Dis. 2004;189(7):1151-7.

55. Tseng C-H, Jeng K-S, Lai MMC. Transcription of subgenomic mRNA of hepatitis delta virus requires a modified hepatitis delta antigen that is distinct from antigenomic RNA synthesis. J Virol. 2008;82(19):9409-16.

56. Chudy M HK-M, Bozdayi M, Kre $\beta$ J, Nübling CM. Collaborative study to establish a World Health Organization International Standard for hepatitis $D$ virus RNA for nucleic acid amplification technique (NAT)-based assays World Health Organization. http://www.who.int/biologicals/expert_ committee/BS_2227_HDV_RNA.pdf. Accessed 21 to 25 October 2013.

57. WHO Expert Committee on Biological Standardization, sixty-fourth report. World Health Organization. 2014. https://apps.who.int/iris/handle/ 10665/129494.

58. Kleiboeker SB. Applications of competitor RNA in diagnostic reverse transcription-PCR. J Clin Microbiol. 2003;41(5):2055-61.

59. Selvey S, Thompson EW, Matthaei K, Lea RA, Irving MG, Griffiths LR. Beta-actin-an unsuitable internal control for RT-PCR. Mol Cell Probes. 2001;15(5):307-11. 
60. Karataylı E, Altunoğlu YÇ, Karataylı SC, Alagöz SGK, Cınar K, Yalçın K, et al. A one step real time PCR method for the quantification of hepatitis delta virus RNA using an external armored RNA standard and intrinsic internal control. J Clin Virol Off Publ Pan Am Soc Clin Virol. 2014;60(1):11-5.

61. Karataylı E, Altunoğlu YÇ, Karataylı SC, Yurdaydın C, Bozdayı AM. Free circulating nucleic acids in plasma and serum as a novel approach to the use of internal controls in real time PCR based detection. J Virol Methods. 2014;207:133-7.

62. Le Gal F, Dziri S, Gerber A, Alloui C, Ben Abdesselam Z, Roulot D, et al. Performance characteristics of a new consensus commercial kit for hepatitis D virus RNA viral load quantification. J Clin Microbiol. 2017:55(2):431-41.

63. Brichler S, Le Gal F, Butt A, Chevret S, Gordien E. Commercial real-time reverse transcriptase $P C R$ assays can underestimate or fail to quantify hepatitis delta virus viremia. Clin Gastroenterol Hepatol Off Clin Pract Am Gastroenterol Assoc. 2013;11(6):734-40.

64. Le Gal F, Brichler S, Sahli R, Chevret S, Gordien E. First international external quality assessment for hepatitis delta virus RNA quantification in plasma. Hepatology. 2016;64(5):1483-94.

65. Wang C, Shen X, Lu J, Zhang L. Development of a reverse transcriptionloop-mediated isothermal amplification (RT-LAMP) system for rapid detection of HDV genotype 1. Lett Appl Microbiol. 2013;56(3):229-35.

66. Notomi T, Okayama H, Masubuchi H, Yonekawa T, Watanabe K, Amino N, et al. Loop-mediated isothermal amplification of DNA. Nucleic Acids Res. 2000;28(12):E63.

67. Iwamoto T, Sonobe T, Hayashi K. Loop-mediated isothermal amplification for direct detection of Mycobacterium tuberculosis complex, M. avium, and $M$. intracellulare in sputum samples. J Clin Microbiol. 2003;41(6):2616-22.

68. Rizzetto M. Hepatitis D: thirty years after. J Hepatol. 2009:50(5):1043-50.

69. Le Gal F, Brichler S, Drugan T, Alloui C, Roulot D, Pawlotsky J-M, et al. Genetic diversity and worldwide distribution of the deltavirus genus: a study of 2152 clinical strains. Hepatology. 2017;66(6):1826-41.
70. Castelnau C, Le Gal F, Ripault M-P, Gordien E, Martinot-Peignoux M, Boyer $\mathrm{N}$, et al. Efficacy of peginterferon alpha-2b in chronic hepatitis delta: relevance of quantitative RT-PCR for follow-up. Hepatology. 2006:44(3):728-35.

71. Madej RM, Davis J, Holden MJ, Kwang S, Labourier E, Schneider GJ. International standards and reference materials for quantitative molecular infectious disease testing. J Mol Diagn JMD. 2010;12(2):133-43.

72. Dhanasekaran S, Doherty TM, Kenneth J. Comparison of different standards for real-time PCR-based absolute quantification. J Immunol Methods. 2010;354(1-2):34-9.

73. Evers DL, Slemons RD, Taubenberger JK. Effect of preservative on recoverable RT-PCR amplicon length from influenza A virus in bird feces. Avian Dis. 2007:51(4):965-8.

74. Uhlenhaut C, Kracht M. Viral infectivity is maintained by an RNA protection buffer. J Virol Methods. 2005;128(1-2):189-91.

75. Hersberger M, Nusbaumer C, Scholer A, Knöpfli V, von Eckardstein A. Influence of practicable virus inactivation procedures on tests for frequently measured analytes in plasma. Clin Chem. 2004;50(5):944-6.

76. Dreier J, Störmer M, Kleesiek K. Use of bacteriophage MS2 as an internal control in viral reverse transcription-PCR assays. J Clin Microbiol. 2005;43(9):4551-7.

77. Pasloske BL, Walkerpeach CR, Obermoeller RD, Winkler M, DuBois DB. Armored RNA technology for production of ribonuclease-resistant viral RNA controls and standards. J Clin Microbiol. 1998;36(12):3590-4.

78. Pickett GG, Peabody DS. Encapsidation of heterologous RNAs by bacteriophage MS2 coat protein. Nucleic Acids Res. 1993;21(19):4621-6.

\section{Publisher's Note}

Springer Nature remains neutral with regard to jurisdictional claims in published maps and institutional affiliations.
Ready to submit your research? Choose BMC and benefit from:

- fast, convenient online submission

- thorough peer review by experienced researchers in your field

- rapid publication on acceptance

- support for research data, including large and complex data types

- gold Open Access which fosters wider collaboration and increased citations

- maximum visibility for your research: over $100 \mathrm{M}$ website views per year

At BMC, research is always in progress.

Learn more biomedcentral.com/submissions 